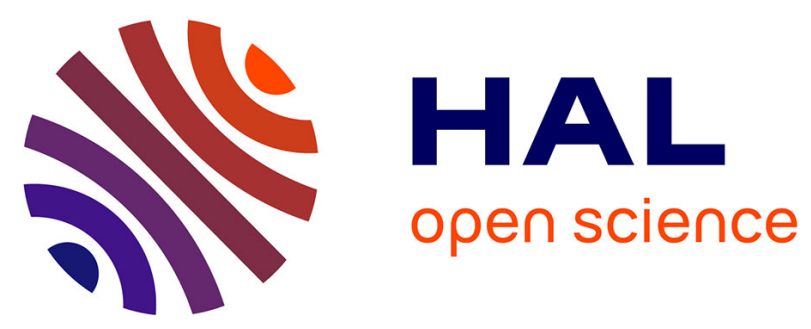

\title{
Low energy 3 He activation analyses for carbon and oxygen
}

\author{
A. Pape, A. Chevallier, J.C. Sens, R. Armbruster
}

\section{To cite this version:}

A. Pape, A. Chevallier, J.C. Sens, R. Armbruster. Low energy 3He activation analyses for carbon and oxygen. Revue de Physique Appliquée, 1969, 4 (2), pp.227-227. 10.1051/rphysap:0196900402022700 . jpa-00243232

\section{HAL Id: jpa-00243232 https://hal.science/jpa-00243232}

Submitted on 1 Jan 1969

HAL is a multi-disciplinary open access archive for the deposit and dissemination of scientific research documents, whether they are published or not. The documents may come from teaching and research institutions in France or abroad, or from public or private research centers.
L'archive ouverte pluridisciplinaire HAL, est destinée au dépôt et à la diffusion de documents scientifiques de niveau recherche, publiés ou non, émanant des établissements d'enseignement et de recherche français ou étrangers, des laboratoires publics ou privés. 


\title{
LOW ENERGY ${ }^{3} \mathrm{He}$ AGTIVATION ANALYSES FOR GARBON AND OXYGEN
}

\author{
A. PAPE, Mme A. GHEVAllier, J. G. SENS et R. ARMBRUSTER, \\ Institut de Recherches Nucléaires, Strasbourg-Cronenbourg.
}

\begin{abstract}
Résumé. - L'observation des rayonnements émis par les isotopes ${ }^{11} \mathrm{C}$ et ${ }^{18} \mathrm{~F}$, produits dans l'activation par ${ }^{3} \mathrm{He}$ du carbone et de l'oxygène, permet de détecter la présence de ces éléments. En utilisant des cibles de composition connue, les sections efficaces des réactions ${ }^{3} \mathrm{He}+\mathrm{C} \rightarrow{ }^{11} \mathrm{C}$ et ${ }^{3} \mathrm{He}+\mathrm{O} \rightarrow{ }^{18} \mathrm{~F}$ ont été mesurées en fonction de l'énergie jusqu'à $5,5 \mathrm{MeV}$. Les résultats obtenus montrent que les sections efficaces pour les deux réactions sont de l'ordre d'une dizaine de $\mathrm{mb}$ pour une énergie des ${ }^{3} \mathrm{He}$ de $2 \mathrm{MeV}$ dans le système du laboratoire. Ceci correspond à une sensibilité de l'ordre de quelque $10^{-6}$ pour l'analyse du carbone et de l'oxygène. La réaction ${ }^{3} \mathrm{He}+\mathrm{N} \rightarrow{ }^{13} \mathrm{~N}$, qui peut être employée pour mettre en évidence la présence d'azote, a une section efficace beaucoup plus faible $\left(^{1}\right)$.
\end{abstract}

Abstract. - Radiations from ${ }^{11} \mathrm{C}$ and ${ }^{18} \mathrm{~F}$ produced in the ${ }^{3} \mathrm{He}$ activation of carbon and oxygen were used to detect the presence of these elements. Using targets of known composition, the cross-sections for the ${ }^{3} \mathrm{He}+\mathrm{C} \rightarrow{ }^{11} \mathrm{C}$ and ${ }^{3} \mathrm{He}+\mathrm{O} \rightarrow{ }^{18} \mathrm{~F}$ reactions were measured as a function of energy up to $5.5 \mathrm{MeV}$. The results show that the cross -sections for both reactions are of the order of tens of $\mathrm{mb}$ at a ${ }^{3} \mathrm{He}$ laboratory energy as low as $2 \mathrm{MeV}$. This corresponds to a sensitivity of the order of ppm for the carbon and oxygen analyses. The ${ }^{3} \mathrm{He}+\mathrm{N} \rightarrow{ }^{13} \mathrm{~N}$ reaction, which can serve as the detecting reaction for nitrogen, was found to have much lower cross-sections $\left({ }^{1}\right)$.

(1) Cette étude a fait l'objet d'une publication, Nucl. Instr. Methods, 1966, 42, 269. 